\title{
Agroforestry: Opportunities and Challenges in Timor-Leste
}

\author{
Shyam Paudel ${ }^{1}$, Himlal Baral ${ }^{2,3}\left(\mathbb{D}\right.$, Adelino Rojario ${ }^{4,5}\left(\mathbb{0}\right.$, Kishor Prasad Bhatta ${ }^{6,7}\left(\mathbb{D}\right.$ and Yustina Artati ${ }^{2, *}$ \\ 1 CTA, United Nation Environment Program (UNEP), Ministry of Natural Resources and Environment, \\ Vientiane P.O. Box 7864, Laos; shyam.paudel@un.org \\ 2 Center for International Forestry Research (CIFOR), Bogor 16115, Indonesia; h.baral@cgiar.org \\ 3 School of Ecosystem and Forest Science, University of Melbourne, Parkville, VIC 3010, Australia \\ 4 Faculty of Forestry and Environment, IPB University, Bogor 16680, Indonesia; roadelino56@gmail.com \\ 5 Department of Reforestation Soil and Water Conservation, Directorate of Forestry Coffee and Industrial Plant, \\ Ministry of Agriculture and Fisheries (GDFCIP), Dili P.O. Box No. 008, Timor-Leste \\ 6 Faculty of Forest Science and Forest Ecology, Georg-August-Universität, Busgenweg 5, \\ 37077 Gottingen, Germany; k.bhatta@stud.uni-goettingen.de \\ 7 Research and Development Center (RDC), Durbarmarg, Kathmandu 44600, Nepal \\ * Correspondence: y.artati@cgiar.org
}

Citation: Paudel, S.; Baral, H.;

Rojario, A.; Bhatta, K.P.; Artati, Y.

Agroforestry: Opportunities and Challenges in Timor-Leste. Forests 2022, 13, 41. https://doi.org/ 10.3390/f13010041

Academic Editor: Bradley B. Walters

Received: 31 October 2021

Accepted: 25 November 2021

Published: 1 January 2022

Publisher's Note: MDPI stays neutral with regard to jurisdictional claims in published maps and institutional affiliations.

Copyright: (C) 2022 by the authors. Licensee MDPI, Basel, Switzerland. This article is an open access article distributed under the terms and conditions of the Creative Commons Attribution (CC BY) license (https:// creativecommons.org/licenses/by/ $4.0 /)$.

\begin{abstract}
Agro forestry is a land management system that integrates trees, agriculture crops, and animal farming in order to provide a diverse range of ecosystem services. Timor-Leste, the newest country and one of the least developed counties, has faced multidimensional challenges on land use management, including deforestation, land degradation, and poverty. The agroforestry system is recognized as one of the viable options for balancing the socio-economic needs and ecological functions of the lands in Timor-Leste. The system has been practiced traditionally by farmers in the country; however, the lack of knowledge and experience, limited institutional capacity, and lack of funding have impeded the wider implantation of the agroforestry system in Timor-Leste. The Strategic Development Plan of Timor-Leste has recommended sustainable agriculture and natural resources management in the rural areas of the country to generate income and create employment for the youths. The paper presents the initiatives, challenges, and opportunities of agroforestry application in Timor-Leste to support sustainable forest management and livelihood improvement. Learning from existing initiatives, capacity building, market access, and financial incentives could promote the agroforestry system in the country.
\end{abstract}

Keywords: agroforestry; livelihood; food security; climate change; resilience; Timor-Leste

\section{Background and Problem}

The Democratic Republic of Timor-Leste is a small, new, developing nation that lies adjacent to Indonesia and Australia. Even though $80 \%$ of the population is involved in agriculture for their living [1], about $75 \%$ of the population in this state is under food insecurity of different intensities [2]. Low agricultural productivity, low value livelihood strategies, and high dependency on a single livelihood strategy were determined as the key factors causing food insecurity [2]. Furthermore, the country has been facing several development challenges including severe human and institutional capacity gaps, unstable economic growth, and heavy socio-economic pressure on the forest and natural resources due to the rapidly increasing population [3]. In addition, the state lies under a climatically vulnerable region prone to several disasters including flash floods, droughts, unpredictable rain, storm wind, river-bed collapse, paddy field destruction, landslides, and destructive winds [4,5]. Due to low economy of Timor-Leste, an integrated approach to ensure food security and to cope with climatic hazard is necessary.

Since mountainous landscape with more than $40 \%$ slope covers about $44 \%$ of the total area of the country, the amount of arable land is limited [6]. Only about 155,000 hectares of land, which forms $10.4 \%$ of the total land in Timor-Leste, is arable [7]. About $80 \%$ of 
households are engaged in crop production, mostly maize, legumes, and tubers, and $86 \%$ are engaged in livestock, rearing mainly chickens pigs, cattle, and goats [8]. The agriculture practice is primarily traditional, subsistence-based, and the productivity is low due to the variability of rainfall, lack of irrigation facilities, droughts, poor soil fertility, lack of organic fertilizers, and agriculture inputs [9]. The commercial farming is restricted by the small farm size and undeveloped marketing infrastructure [8]. On the other side, slash-and-burn agriculture - a traditional practice to compensate for reduced crop yields-is alleged to trigger deforestation and forest fire [10]. In addition, the unclear land tenure system due to resistance by elites to the full recognition of customary land management is claimed to delimit the commercial farming system in Timor-Leste [11].

Forest in Timor-Leste covers an area of 925,000 hectares i.e., about $61 \%$ of total land, but it undergoes an annual declination of $0.15 \%$ [12]. About $93 \%$ of households derive their energy from wood [13], whereas about 39\% of the population collect food from the forest [14]. The population in Timor-Leste is increasing by $2.7 \%$ per year, and by 2030 , it is estimated to reach 1.8 million [15]. The constant pressure on forest due to the increasing population has induced the natural hazards [16]. The vulnerability of communities in Timor-Leste to climate-induced disasters will further increase owing to maladaptive responses that cause environmental degradation [16,17]. These degradations resulting from unsustainable farming techniques such as slash-and-burn agriculture and the reduced practice of traditional terrace farming demand a sustainable farming strategy [18]. The pressure from environmental hazards and low food productivity has created a necessity to develop a strategy to manage land in such a way to maximize the profit. This opinion paper aims to understand the status, opportunities, and challenges of developing agroforestry as an integrated land use management system in Timor-Leste. The analysis draws from a literature review.

\section{Agroforestry in Timor-Leste}

There are various definitions of agroforestry from different experts; one [19] defines agroforestry as an integrated land use system in which social and ecological aspects are embedded in the system combining trees and agricultural crops and/or livestock, either simultaneously or successively. In another definition, agroforestry is a collective term for various land use systems and technologies designed for a single unit of land. It is applied by combining woody plants (trees, shrubs, palms, and bamboos) and agricultural crops or animals (livestock and/or fish), simultaneously or consecutively to promote ecological and economic interactions among the components [20]. Overall, it is a land management system that integrates trees, agriculture crops, and animal farming in order to provide a diverse range of ecosystem services by bridging the gaps between agriculture, forestry, and animal husbandry [21,22]. It involves economic and ecological interactions between two or more production systems such as tree-crop, tree-livestock, or tree-fish [22]. Different types of agroforestry practices such as agrosilviculture, silvopasture, agrosilvopasture, forest farming, etc. are adopted by farmers that provide different types of ecosystem services that include provisioning services: food fiber, freshwater, raw materials, fuelwood, nontimber forest products (NTFPs), medicinal resources, genetic resources, and ornamental resources; regulating ecosystem services such as erosion control, climate change moderation, nutrient retention, carbon storage and sequestration, and pest control; and habitat services including biodiversity enhancement and climate regulation [22-25]. Agroforestry can also increase profits by increasing plant diversity, improving agricultural productivity, preventing land degradation and soil erosion, and reducing the risk of crop failure and the need for fertilizers [26].

Timor-Lestes's Strategic Development Plan 2011 to 2030 identifies increasing agrobiodiversity with a focus on nutritious and high-yield crops including coffee, coconut, and other potential cash crops such as cocoa, cashews, hazelnuts, and spices [27]. The Ministry of Agriculture and Fisheries Strategic Plan has outlined the country's agricultural goals: (i) increase rural incomes and reduce poverty, (ii) promote environmental sustainability 
and conservation of natural resources, (iii) sustainably increase food production through improved crop varieties, forestry, livestock species, and fisheries, (iv) conserve, manage, and utilize natural resources [28].

The rehabilitation of degraded watersheds in Timor-Leste is prioritized by the National Biodiversity Strategy and Action Plan [29] whereas the Basic Environmental Law of Timor-Leste [30] aims to reduce the pressures on natural resources and promote landscape conservation for ecosystem services. Therefore, agroforestry has been identified as one of the key approaches to balance the agriculture product to sustain livelihoods and to rehabilitate degraded watersheds for enhanced ecosystem services [31]. Agroforestry has been providing a wide range of services and benefits to the local communities. It is traditionally used to control erosion and reduce flood in hilly regions. Agroforestry significantly contributes the supply of fodder for domesticated livestock and fuelwood for household energy. Local communities commonly prefer fruit trees such guava, avocado, etc. for domestic consumption as well as to generate cash income by selling in rural markets. However, there is no actual estimation of cash income generation from agroforestry fruit trees.

According to the UNDP [26], four different agroforestry models are common in Timor-Leste (Figure 1). (i) Alley cropping involves planting in the alley between rows of hedges/trees arranged according to contour lines. This model has been adopted mostly in hilly regions to reduce the occurrence of landslides and to facilitate the flow of water on a long-term basis. (ii) The trees-along border pattern involves planting trees/shrubs along the border (hedgerow). This is mostly practiced in steep hilly areas to conserve soil. (iii) Random mixers involves irregularly spacing trees while planting and simultaneously growing the annual crop in stratum underneath. This practice is mostly found in low land areas. (iv) Alternate rows involves planting trees in regular alternate rows and seasonal cultivation done in the space in between the rows. This pattern is practically suitable for flat and wide areas. This practice is not so common in Timor-Leste but can be seen in some places [26].
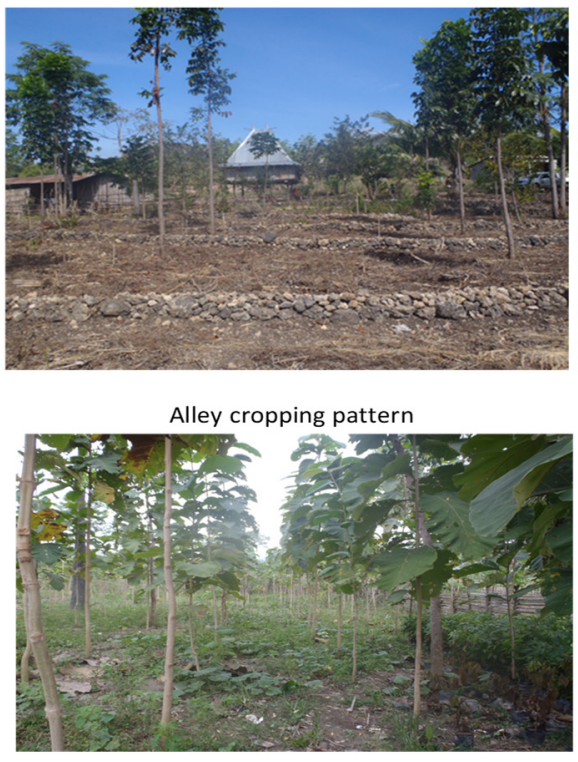

Alternate row pattern

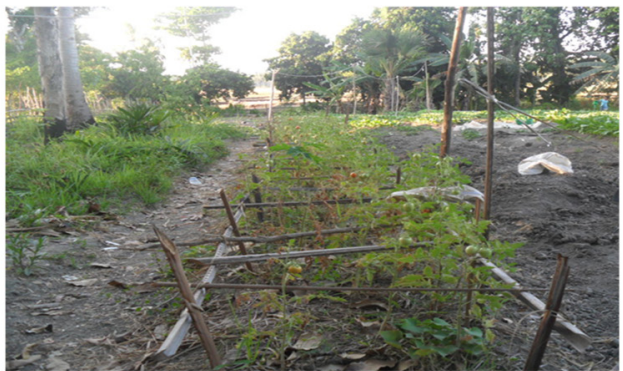

Tree along border pattern

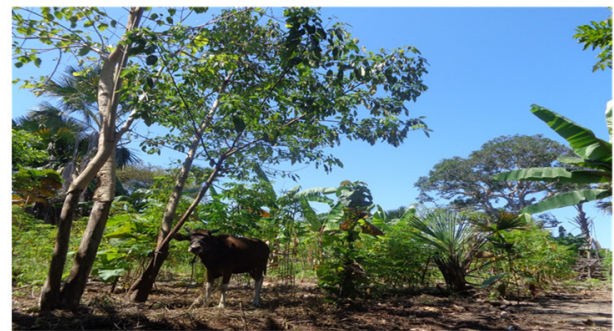

Irregular pattern

Figure 1. Various agroforestry models in Timor-Leste (Photos: Adelino/GDFCIP).

Fukuoka, a natural farming system, was introduced in Timor-Leste to plant trees in hilly agricultural marginal lands. About 200,000 Fukuoka seedballs were produced and distributed to rehabilitate larger vulnerable slopes previously damaged by slash-and-burn agriculture, erosion, and other forms of ecosystem degradation in hilly landscapes [32]. Fukuoka is a non-destructive type of reforestation method that can be used in hilly regions 
without tilling the ground. This has been widely practiced as it is easy, cheap, and nondestructive in erosion-prone landscapes [26]. However, the success rate was only about $50 \%$ mainly due to the lack of rain following the dispersal of the seed balls, browsing by animals in early stages, and poor seed quality.

According to Friday [33], fruit and fodder trees are among the major preferred species for agroforestry in Timor-Leste. In dryland, the preferred agroforestry species for forage include Acacia leucophloea, Albizia lebbek, Hibiscus tiliaceus, and Prosopis spp. Similarly, in areas with moderate rainfall, the preferred species are Gliricidia sepium, Sesbania grandiflora, Samanea saman, and Leucaena leucocephala. Other possible forage trees that exist in Timor-Leste that could be used for agroforestry include Calliandra calothyrsus, Paraserianthes falcataria, and Albizia chinensis [33].

\section{Agroforestry: Initiatives, Challenges, and Opportunities}

\subsection{Current and Proposed Initiatives}

Finding agroforestry as a viable option to restore landscape, sustain agriculture, and provide multiple livelihood benefits, several initiatives on agroforestry have been commenced in Timor-Leste funded by different donors. The United Nations Development Program's (UNDP) Global Environment Facility (GEF) funded projects on strengthening the community resilience along with the Dili to Anairo Road Development Corridor (DARDC) project, which was implemented from 2014 to 2019. The project aimed to build the resilience of watershed systems by improving natural resources management including forest, soil, and water in order to provide sustained ecosystem services to local communities. Agroforestry was considered as one of the key interventions to enhance ecosystem services [4]. The project introduced agroforestry systems in more than 200 ha of community land and introduced the Fukuoka system as a non-destructive and cost-effective way of plantation in hilly regions. Until 2018, 84.5 hectares of agroforestry had been completed. The UNDP worked closely with the National Directorate of Forestry within the Ministry of Agriculture and Fisheries (MAF) to reduce potential risks from disaster alongside building the resiliency of local people through reforestation and agroforestry [4]. The project used tara bandu (a local land law) to facilitate the planning and implementation of agroforestry at the community level $[4,34]$. The activity involved the collaboration of local MAF extension officers and NGOs during implementation to support the replication and sustainability of the interventions [4,34]. MAF has already been working with local and international NGOs to implement and promote reforestation interventions such as the planting of firewood trees (e.g., Casuarina), establishment of Eucalyptus nurseries, and restoration of mangroves [35]. Similarly, the European Union (EU) and Government of Germany through the Federal Ministry for Economic Cooperation and Development (BMZ) (in German: Bundesministerium für wirtschaftliche Zusammenarbeit und Entwicklung) have co-financed the project "Partnership for Sustainable Agroforestry" (PSAF), which has been implemented with the support of MAF in Timor-Leste from 2017 to 2022. The project aims to support more than 4000 households from four municipalities (Manatuto, Baucau, Viqueque, and Lautem) to adopt agroforestry and afforestation practice. The project has included a range of species such as Mahogany (Swietenia spp.), Teak (Tectona grandis), Sandalwood (Santalum album), ai-saria (Cedrella toona), Leucaena (Leucaena spp.), Rosewood tree (Dysoxylum arborescens), Orange (Citrus sinensis), Snake fruit (Salacca edulis), Mango (Magnifera indica), and Cashew nut (Anarcadium occidentale). The objective of the project is to provide an opportunity to marginalized people, in particular young men and women in rural areas, to benefit from better employment opportunities in the agroforestry systems of Timor-Leste. Specifically, this project aims to increase the productivity of agroforestry systems, strengthen the capacity of actors along with selected agroforestry value chains, improve the market access for selected agroforestry products (e.g., fruits and vegetables, raw and processed wood products), and improve the institutional and organizational framework for the promotion of agroforestry [36]. 
Furthermore, as a component of PSAF, ERA-agroforestry (Enhancing Rural Access Agroforestry Project) is being implemented with the support of the EU, Germany, and the International Labor Organization (ILO). The objective of this project is to implement a capacity building and labor-based program to rehabilitate rural roads so as to improve access to agroforestry areas, employment, and economic opportunities for local population [37].

The Agriculture Development Bank (ADB) [38] has proposed an initiative on Innovative Partnerships for coffee and agroforestry development. The project envisaged that improvements in coffee production and processing offers one of the clearest pathways for reducing poverty and growing Timor-Leste's non-oil economy. Coffee provides an important source of cash income for around $27.5 \%$ of Timorese households and is the largest non-oil export of the country [39]. However, the coffee sector is currently operating far below its long-term potential due to low and volatile production, inconsistent quality, and weak sector management. Strengthening sector management and providing targeted support to smallholder producers can generate sustained increases in household income. If implemented at scale, this could have a significant impact on the national poverty rate and growth of non-oil exports [39].

To help farmers defend their land ownership rights, adopt sustainable farming practices, and strengthen economic situations, an organization UNAER (Unian Agrikultor de Ermera) based in the Ermera municipality has been established in partnership with Union Aid Abroad-APHEDA [36]. With the support of this project, the farmers have grown a variety of alternative fruits including banana, papaya, lemon, mandarin, etc., in the non-coffee season and sold directly to buyers [40].

\subsection{Key Challenges}

Agriculture and natural resources are the main source of livelihood for rural communities [13]. About $75 \%$ of the total population face challenges of sustaining their livelihoods due to disaster risks, low food production, and lack of infrastructures [27]. Rural communities lack infrastructures such as water storage and irrigation facilities to increase their agriculture production and need to rely on rain-fed agriculture [41]. Unsustainable agricultural practice and the over-harvesting of natural resources are common in rural areas [42]. Deforestation, forest degradation, and the expansion of unsustainable subsistence farming are the major issues and the largest emitters of greenhouse gases in the country [38]. Agroforestry could be one of the viable options for balancing the socio-economic needs and ecological functions of the land [43]. However, a lack of knowledge and experience on improved agroforestry system impedes the wider implantation of an agroforestry system in the country. The incompetency of the government in providing technical inputs to farmers at the local level has also restricted the development of agroforestry in Timor-Leste [44].

A lack of cash flow and financial access is another major hurdle for agroforestry practice [45]. Based on the UNDP project experience, communities were motivated for agroforestry if provided with cash incentives for planting trees ( 25 cents per plant) besides providing free seedlings. They also expected cash enticements for protection and taking care of the plants [46,47]. Some donor-funded projects have been providing such incentives to farmers, but the approach has been under debate regarding its sustainability. However, according to the ADB's proposed project, assisting smallholder farmers to access formal financial services would enable them to build up savings and to access credit on more favorable terms [39]. This would complement and reinforce interventions to increase smallholder productivity.

Since $80 \%$ of the country is difficult to access due to a lack of good road networks, farmers have been facing challenges in selling their agricultural products [48]. The involvement of middlemen has delimited farmers from receiving fair prices for their agricultural products. This has demotivated farmers from investing in improved agricultural systems, including agroforestry practices [49]. Even though livestock forms one of the major sources of food and income for $80 \%$ of households in Timor-Leste, the current practice of allowing 
free grazing in the forest is a huge jeopardy for agroforestry [50,51]. Many agroforestry projects in past have faced this challenge and therefore failed to achieve their objective.

The major problems in developing agroforestry in Timor-Leste also include the lack of human resources and low level of education of formal institutions [52]. The agricultural extension services delivered by MAF staff and donor projects in Timor-Leste experienced difficulties because of the high expectations of landholders, lower education, lower trust in government, and poor skills among extension agents [53]. In addition, the lack of a proper agroforestry model as an alternative tool to improve community livelihood and improve the forest area and lack of legal forest management rights for communities are key challenges in developing the agroforestry in Timor-Leste [52].

Moreover, the unclear and complicated land tenure system of Timor-Leste has also discouraged private investors from investing in large-scale agroforestry [38,54]. There is still a great division between those who wish to exercise customary practices fully protected by law and those who wish to abolish customary rights and replace these by other forms of ownership that include state control and private property [11]. Reforming the law relating to land tenure is crucial for encouraging private investment for long terms.

\subsection{Opportunities and Way Forward}

The strategic development plan (SDP 2011-2030) of Timor-Leste has acknowledged the fact that the creation of local jobs through improved agriculture and natural resource management could be the best way to improve the livelihood of people living in rural areas [27]. Timor-Leste has an ample amount of land areas with suitable climate and soil to grow a wide range of valuable tropical trees in combination with agriculture. According to the ADB [38], around 32,500 hectares of suitable land that is not currently forested, protected or cultivated is available in Timor-Leste, which could be used for the largescale implementation of agroforestry practices, which in turn would generate significant employment opportunities to $70 \%$ of its young population. There are opportunities to maximize the benefits by expanding the range of products from the agroforestry sector for the export market and natural resource restoration by developing community-based nurseries, training rural populations in agroforestry establishment.

The government of Timor-Leste is committed to protecting around $73 \%$ of land areas for the conservation of water resources, soil, and biodiversity by 2023 , which includes $228,174.57$ ha of dense forest cover, 278,999.19 ha of sparse forest cover, and 238,508.55 ha of non-forest areas [17]. Agroforestry could be one of the viable options for reversing land degradation. As Timor-Leste does not have a specific policy and strategy on agroforestry development., the country can learn a lot from its neighboring country Indonesia to develop and implement agroforestry strategy. Indonesia developed national strategy for agroforestry research (2013-2030) focusing on (i) smallholder production systems and markets, (ii) community-based forest management on state forest areas, (iii) the harmonization of agroforestry practices with global climate change, and (iv) enhancing agroforestry practices for environmental services [55]. Lessons from the adoption of agroforestry on state land in Indonesia, securing tenure right through agroforestry practice on state land, could be a reward of farmers to make the land more sustainable [56]. Timor-Leste can also learn from other regions such as planting trees and shrubs as nitrogen-fixing green fertilizers to increase average maize yields and to stabilize crop production in drought years and during other extreme weather events in southern Africa [57]. The Malawi Agroforestry Food Security Program is also a good example where improved green fertilizer technologies increased maize yields [58]. Timor-Leste also needs to prioritize diversification of the agriculture sector through a planned agroforestry system by planting high-value trees including sandalwood and teak, and non-timber products, such as bamboo, cocoa, coconuts, spices, coffee, perennial fruits, nuts, and animal fodder, integrated with livestock developments, need to be prioritized in MAF's strategy. Land tenure issues should be addressed to ensure maximum benefits for smallholders and to support the development of accessible agroforestry inputs by liaising with the private sector. A mixed agroforestry 
model for diversification would provide rural households to expand their sources of food and income and build their resiliency to climate change [59].

The current initiatives on agroforestry from different donor-funded projects have provided opportunities to learn skills and engage communities in the agroforestry system $[36,40]$. There is already a system-wide realization that agroforestry would be a viable option to build watershed resiliency and diversify income from agriculture and forestry. Furthermore, the government of Timor-Leste has intended to increase the number of national fisheries and aquaculture programs to sustainably improve livelihoods. With the support of the Food and Agriculture Organization (FAO), the government has expected to improve the livelihood of local people and build the capacity of fisherfolks and their supporting institutions, thus providing a huge opportunity for the development of silvo-aquaculture [60].

Agroforestry could also contribute to DRR and build community resiliency in TimorLeste [61,62]. Timor-Leste is highly vulnerable to climate change and disaster risks due to its hilly geographical terrain [5]. Flood and erosions are common throughout the country during the rainy season [5]. Therefore, agroforestry could be a practical solution to control soil erosion and maintain land fertility in the hilly regions and thereby build the resilience of the local communities depending upon agriculture and natural resources for their livelihoods [62]. The fifth assessment report of Intergovernmental Panel on Climate Change (IPCC) has suggested an integrated strategy such as agroforestry to address climate change [63]. Agroforestry, the diversification of crops, and the use of A-frame terracing come under the most potential cost-effective climate change mitigation options in TimorLeste [61]. The adoption of an agroforestry development strategy could facilitate the growth of agroforestry in Timor-Leste [52].

Following the requirement of resilience against natural calamities and the limited amount of arable land, agroforestry could be the best strategy to diversify the land use and prevent land degradation in Timor-Leste. An approach to develop agroforestry at a wider scale in Timor-Leste through technical support to maximize food production, financial investments, infrastructure development, policy intrusions, and land ownership rights is required $[54,57,61]$.

\section{Conclusions}

Timor-Leste has been facing the problem of food insecurity alongside climatic catastrophes. With limited arable land and high population, agroforestry is recognized as a reliable strategy to maximize food production and cope with climatic vulnerabilities. Different kinds of agroforestry systems, including alley cropping, alternate row planting, random mixers, and trees along borders are adopted in Timor-Leste. The Fukuoka system is widely accepted to rehabilitate the degraded landscape. Fruit and fodder species were preferred for the agroforestry. Several projects such as DARDC, tara bandu, and PSAF have initiated the plantation programs for agroforestry, market development, and strengthening the capacity of institutions for the implementation of agroforestry projects. However, the lack of financial access, infrastructures, irrigation facilities, vulnerability to climatic hazards, and unclear land ownership rights have created a challenge for the wide acceptance of agroforestry system in Timor-Leste. On the other side, a support from donor agencies and the government have provided the local people with the skills and knowledge about agroforestry systems and its associated benefit in employing young people and building resilience against climate change, which has created an opportunity for the adoption of agroforestry at a larger scale. Capacity building, financial incentives, market accessibility, and infrastructure development are required to further foster agroforestry in Timor-Leste. 
Author Contributions: Conceptualization, H.B., S.P. and A.R.; methodology, S.P. and A.R.; validation, S.P. and H.B.; investigation, S.P. and Y.A.; resources, S.P., A.R. and K.P.B.; data curation, S.P. and K.P.B.; writing-original draft preparation, S.P., K.P.B. and H.B.; writing-review and editing, H.B., S.P. and Y.A.; supervision, H.B.; funding acquisition, Y.A. and H.B. All authors contribute to the manuscript and approve final draft. All authors have read and agreed to the published version of the manuscript.

Funding: The publication of this manuscript was funded by the CGIAR research program on Forest, Tree, and Agroforestry (FTA).

Institutional Review Board Statement: Not applicable.

Informed Consent Statement: Not applicable.

Data Availability Statement: Not applicable.

Acknowledgments: The authors are thankful to a number of individuals at the General Directorate of Forestry, Coffee, and Industrial Plant of Ministry of Agriculture and Fisheries (GDFCIP), Timor Leste and UNDP Timor-Leste office. Many thanks are also extended to all colleagues who shared their precious time, thoughts and concerns on agroforestry and restoration in Timor Leste. Our gratitude is to the CGIAR Research Program on Forest, Tree, and Agroforestry (FTA) for funding support to publish the work.

Conflicts of Interest: The authors declare no conflict of interest.

\section{References}

1. General Directorate of Statistics (GDS). Timor-Leste Agriculture Census 2019, National Report on Final Census Results, General Directorate of Statistics, Ministry of Finance and Ministry of Agriculture and Fisheries. 2020. Available online: http://www.fao.org/fileadmin/templates/ess/ess_test_folder/World_Census_Agricuture/WCA_2020/WCA_2020_new_ doc/TLS_REP_ENG_2019_01.pdf (accessed on 10 February 2021).

2. Ministry of Agriculture and Fisheries (MAF). The Integrated Food Security Phase Classification (IPC). 2019. Available online: http://www.ipcinfo.org/fileadmin/user_upload/ipcinfo/docs/3_IPC_Timor\%20Leste_CFI_20182023_English.pdf (accessed on 12 February 2021).

3. United Nations Development Programme (UNDP). Country Program for Timor-Leste 2009-2013. 2008. Available online: http:/ / www.undp.org/content/dam/rbap/docs/programme-documents/TL-CP-2009-2013.pdf (accessed on 14 February 2021).

4. United Nations Development Programme (UNDP). Strengthening Community Resilience to Climate-Induced Disasters in the Dili to Ainaro Road Development Corridor. 2019. Available online: https://www.tl.undp.org/content/timor_leste/en/home/ all-projects / DARDC.html (accessed on 2 March 2021).

5. European Union (EU). Disaster Preparedness in Timor-Leste. Disaster Preparedness, Humanitarian Aid and Civil Protection Directorate General (DIPECHO), and Timor Leste Living Standards Survey. 2007. Available online: https:/ / ec.europa.eu/echo/ files/policies/dipecho/presentations/est_timor.pdf?fbclid=IwAR26DqR3-5W1KmBhmEs1jVVXfJAEJfDwn1Mk78PcU_Vw-U6 PUrXf8o4uYv4 (accessed on 14 February 2021).

6. Barnett, J.; Dessai, S.; Jones, R.N. Vulnerability to climate variability and change in East Timor. AMBIO 2007, 36, 372-378. [CrossRef]

7. World Bank. World Development Indicators. Arable Land (hectares) Timor Leste (DataBank). 2018. Available online: https: / / data.worldbank.org/indicator/AG.LND.ARBL.HA?locations=TL (accessed on 13 February 2021).

8. Ministry of Finance, Timor-Leste. Ministry of Finance (MOF)Launch of the Main Results of the 2015 Census of Population and Housing. 2016. Available online: https:/ / www.statistics.gov.tl/wp-content/uploads/2015/10/1-Preliminary-Results-4-PrintingCompany-19102015.pdf (accessed on 15 September 2021).

9. Cruz, C.J. Improving food security through agricultural development in Timor-Leste: Experiences under 13 years of democratic government. In Australian Center for International Agricultural Research (ACIAR) Proceedings Series; Australian Centre for International Agricultural Research (ACIAR): Canberra, Australia, 2016; pp. 30-37.

10. Food and Agricultural Organization (FAO). FAO in Timor-Leste. 2019. Available online: http://www.fao.org/timor-leste/news/ detail-events/fr/c/1197518/ (accessed on 17 February 2021).

11. Batterbury, S.; Palmer, L.; Reuter, T.; de Carvalho, D.D.A.; Kehi, B.; Cullen, A. Land access and livelihoods in post-conflict Timor-Leste: No magic bullets. Int. J. Commons 2015, 9, 619-647. [CrossRef]

12. Food and Agricultural Organization (FAO). Global Forest Resource Assessment. Report Timor-Leste, Food and Agriculture Organization of the United Nations, Rome. 2020. Available online: http:/ / www.fao.org/3/cb0077en/cb0077en.pdf (accessed on 21 February 2021).

13. Gonzaga Fraga, L.; Teixeira, C.F.; Ferreira, E.C. The potential of renewable energy in Timor-Leste: An assessment for biomass. Energies 2019, 12, 1441. [CrossRef]

14. Hosgelen, M.; Saikia, U. Forest reliance as a livelihood strategy in Timor-Leste. Underst. Timor-Leste 2014, II, 66-73. 
15. National Statistics Directorate (NDS). Population and Housing Census. Government of Timor-Leste, Ministry of Finance, General Directorate of Statistics; and United Nations Population Fund. 2010. Available online: https:/ /www.statistics.gov.tl/wp-content/ uploads/2013/12/English_20Census_20Preliminary_20Results_202010.pdf?fbclid=IwAR3ZunGqy8AJj4RgRbe6USXecddjRW1 3I4HX15ThavpXFQGL0Au1XdlPxKY (accessed on 16 February 2021).

16. Molyneux, N.; Da Cruz, G.R.; Williams, R.L.; Andersen, R.; Turner, N.C. Climate change and population growth in Timor Leste: Implications for food security. AMBIO 2012, 41, 823-840. [CrossRef]

17. Ministry of Agriculture and Fisheries (MAF). Final Country Report of the Land Degradation neutrality Target Setting Programme in Timor-Leste. 2018. Available online: https://knowledge.unccd.int/sites/default/files/ldn_targets/2019-01/Timor-Leste\%20 LDN\%20TSP\%20Country\%20Report.pdf (accessed on 21 February 2021).

18. Asian Development Bank (ADB). Country Partnership Strategy for Timor Leste 2016-2020. 2016. Available online: https: / / www.adb.org/sites/default/ files/institutional-document/183715/cps-tim-2016-2020.pdf (accessed on 26 February 2021).

19. Nair, P.R. An Introduction to Agroforestry; Springer: Dordrecht, The Netherlands, 1983; Available online: http:/ / apps.worldagroforestry. org/Units/Library/Books/PDFs/32_An_introduction_to_agroforestry.pdf?n=161 (accessed on 15 September 2021).

20. Lundgren, B.O.; Raintree, J.B. Sustained Agroforestry. In Agricultural Research for Development: Potentials and Challenges in Asia; Nestel, B., Ed.; ISNAR: The Hague, The Netherlands, 1982; pp. 37-49.

21. Oelbermann, M.; Voroney, R.P.; Gordon, A.M. Carbon sequestration in tropical and temperate agroforestry systems: A review with examples from Costa Rica and southern Canada. Agric. Ecosyst. Environ. 2004, 104, 359-377. [CrossRef]

22. Shin, S.; Soe, K.T.; Lee, H.; Kim, T.H.; Lee, S.; Park, M.S. A Systematic Map of Agroforestry Research Focusing on Ecosystem Services in the Asia-Pacific Region. Forests 2020, 11, 368. [CrossRef]

23. de Oliveira, R.E.; Carvalhaes, M.A. Agroforestry as a tool for restoration in atlantic forest: Can we find multi-purpose species? Oecol. Aust. 2016, 20, 425-435. [CrossRef]

24. Jose, S. Agroforestry for ecosystem services and environmental benefits: An overview. Agrofor. Syst. 2009, 76, 1-10. [CrossRef]

25. Chang, C.H.; Karanth, K.K.; Robbins, P. Birds and beans: Comparing avian richness and endemism in arabica and robusta agroforests in India's Western Ghats. Sci. Rep. 2018, 8, 3143. [CrossRef]

26. United Nations Development Programme (UNDP). Community Agroforestry Guide. UNDP-DARDC Project. 2018. Available online: https://www.tl.undp.org/content/timor_leste/en/home/library/resilience/community-agroforestry-guide.html (accessed on 12 January 2021).

27. Government of Timor-Leste (GoTL). Strategic Development Plan 2011 to 2030, Government of Timor-Leste, Dili, TimorLeste. 2011. Available online: https://www.adb.org/sites/default/files/linked-documents/cobp-tim-2014-2016-sd-02.pdf (accessed on 19 September 2021).

28. Ministry of Agriculture and Fisheries (MAF). Ministry of Agriculture and Fisheries Strategic Plan 2014 to 2020, Ministry of Agriculture and Fisheries, Government of Timor-Leste, Dili, Timor-Leste. 2012. Available online: http://extwprlegs1.fao.org/ docs/pdf/tim149148.pdf (accessed on 20 September 2021).

29. Ministry of Economy and Development (MED). The National Biodiversity Strategy and Action Plane of Timor-Leste (2011-2020). 2011. Available online: https://www.tl.undp.org/content/timor_leste/en/home/library/environment_energy/the-nationalbiodiversity-strategy-and-action-plan-of-timor-lest.html (accessed on 10 February 2021).

30. Democratic Republic of Timor-Leste (RDTL). Environment Basic Law. Decree Law No 26/2012 of 4 July 2012 . Unofficial Translation from Protuguese of the Decree Law as published in the Official Gazette 4 July 2012, Series 1 No 24. 2012. Available online: https:/ / www.laohamutuk.org/Agri/EnvLaw/2012/DL26EnvBasicLaw4Jul2012en.pdf (accessed on 17 February 2021).

31. Garrity, D.P. Agroforestry and the achievement of the Millennium Development Goals. Agrofor. Syst. 2004, 61, 5-17.

32. United Nations Development Programme (UNDP). Local Famers Use Innovative Fukuoka Method to Cultivate Land. 2018. Available online: https://www.tl.undp.org/content/timor_leste/en/home/stories/local-farmers-Fukuoka-method-cultivateland.html (accessed on 27 February 2021).

33. Friday, J.B. Agroforestry opportunities for Timor-Leste. Forage banks and forage gardens. In PowerPoint Presentation, TimorLeste Agricultural Rehabilitation, Economic Growth, and Sustainable Natural Resources Management Project; University of Hawaii: Honolulu, HI, USA, 2005.

34. The Asia Foundation. Tara Bandu: Its Role and Use in Community Conflict Prevention in Timor-Leste. Belun. 2013. Available online: https:/ / asiafoundation.org/resources/pdfs/TaraBanduPolicyBriefENG.pdf (accessed on 28 January 2021).

35. World Vision International. Planting Trees to Re-Green Timor-Leste. 2019. Available online: https://www.wvi.org/timor-leste/ article/ planting-trees-re-green-timor-leste (accessed on 28 January 2021).

36. Deutsche Gesellschaft für Internationale Zusammenarbeit (GIZ). Ai ba Futuru-Partnership for Sustainable Agroforestry. 2020. Available online: https:/ / www.giz.de/en/downloads/giz2020_en_PSAF_Factsheet.pdf (accessed on 10 March 2021).

37. International Labour Organization (ILO). Enhancing Rural Access Agroforestry Project (ERA Agro-forestry). 2019. Available online: https:/ /www.ilo.org/jakarta/whatwedo/projects/WCMS_553152/lang--en/index.htm (accessed on 17 February 2021).

38. Asian Development Bank (ADB). Asian Development Outlook (ADO) 2019: Strengthening Disaster Resilience; ADB: Manila, Philippines, 2019.

39. Asian Development Bank (ADB). Timor-Leste: Innovative Partnership for Coffee and Agroforestry Development. Concept paper. 2018. Available online: https:/ / www.adb.org/sites/default/files/project-documents/51396/51396-001-cp-en.pdf (accessed on 15 March 2021). 
40. Union Aid Board APHEDA. Sustainable Farming and Organizing farmers in Timor Leste. 2018. Available online: https: / / www.apheda.org.au/sustainable-farming-timor-leste/ (accessed on 12 January 2021).

41. Noltze, M.; Schwarze, S.; Qaim, M. Impacts of natural resource management technologies on agricultural yield and household income: The system of rice intensification in Timor Leste. Eco. Econ. 2013, 85, 59-68. [CrossRef]

42. Moore, A.; Dormody, T.; VanLeeuwen, D.; Harder, A. Agricultural sustainability of small-scale farms in Lacluta, Timor Leste. Int. J. Agric. Sust. 2014, 12, 130-145. [CrossRef]

43. Gangadharappa, N.R.; Shivamurthy, M.; Ganesamoorthi, S. Agroforestry-A viable alternative for social, economic and ecological sustainability. In Proceedings of the XII World Agroforestry Congress, Quebec, QC, Canada, 21-28 September 2003.

44. National Action Programme. Timor-Leste National Action Programme to Combat Land Degradation. 2008. Available online: http:/ / www.fao.org/fileadmin/templates/cplpunccd/Biblioteca/bib_TL_/Timor-Leste_NAP_Revised_Draft.pdf (accessed on 3 March 2021).

45. Zinngrebe, Y.; Borasino, E.; Chiputwa, B.; Dobie, P.; Garcia, E.; Gassner, A.; Kihumuro, P.; Komarudin, H.; Liswanti, N.; Makui, P.; et al. Agroforestry governance for operationalising the landscape approach: Connecting conservation and farming actors. Sustain. Sci. 2020, 15, 1417-1434. [CrossRef]

46. Bond, J.; Millar, J.; Ramos, J. Livelihood benefits and challenges of community reforestation in Timor Leste: Implications for smallholder carbon forestry schemes. For. Trees Livelihoods 2020, 29, 187-204. [CrossRef]

47. Enters, T.; Durst, P.B.; Brown, C. What Does it Take? The Role of Incentives in Forest Plantation Development in the Asia-Pacific Region. 2004. Available online: http://www.fao.org/forestry/5247-021bfef4098d1413fbbcd9a64c8103fbd.pdf (accessed on 24 March 2021).

48. Rola-Rubzen, M.F.; Janes, J.A.; Correia, V.P.; Dias, F. Challenges and constraints in production and marketing horticultural products in Timor Leste. In III International Symposium on Improving the Performance of Supply Chains in the Transitional Economies; International Society for Horticultural Science: Leuven, Belgium, 2010; Volume 895, pp. 245-253.

49. Lundahl, M.; Sjöholm, F. Improving the Lot of the Farmer: Development Challenges in Timor-Leste during the Second Decade of Independence. Asian Econ. Pap. 2013, 12, 71-96. [CrossRef]

50. Bettencourt, E.M.V.; Tilman, M.; Narciso, V.; Carvalho, M.L.D.S.; Henriques, P.D.D.S. The livestock roles in the wellbeing of rural communities of Timor-Leste. Rev. Econ. Sociol. Rural 2015, 53, 63-80. [CrossRef]

51. Coimbra, L.; Deus, P.D.; Supriyadi, M. Developing Strategies for Improving Bali Cattle Productivity in Timor-Leste. In Proceedings of the 15th AAAP Animal Science Congress, Pathum Thani, Thailand, 26-30 November 2012.

52. da Silva, F.; Dassir, M.; Mujetahid, M.; Nadirah, S. Collaboration Based Agroforestry Development Strategy in Laubonu Village, Atsabe Subdistrict, District Ermera, Timor Leste. Adv. Environ. Biol. 2019, 13, 10-16.

53. Reid, R. Developing farmer and community capacity in Agroforestry: Is the Australian Master TreeGrower program transferable to other countries? Agrofor. Syst. 2017, 91, 847-865. [CrossRef]

54. Thu, P.M. Access to land and livelihoods in post-conflict Timor-Leste. Aust. Geogr. 2012, 43, 197-214. [CrossRef]

55. Rohadi, D.; Herawati, T.; Firdaus, N.; Maryani, R.; Permadi, P. National Strategy for Agroforestry Research in Indonesia 2013-2030. Center for Research and Development on Forest Productivity Improvement, Forestry Research and Development Agency, Bogor, Indonesia. 2013. Available online: http://simlit.puspijak.org/files/buku/Book_NSAF_English.pdf (accessed on 18 September 2021).

56. Suyanto, S.; Permana, R.P.; Khususiyah, N.; Joshi, L. Land tenure, agroforestry adoption, and reduction of fire hazard in a forest zone: A case study from Lampung, Sumatra, Indonesia. Agrofor. Syst. 2005, 65, 1-11. [CrossRef]

57. Sileshi, G.W.; Akinnifesi, F.K.; Ajayi, O.C.; Muys, B. Integration of legume trees in maize-based cropping systems improves rain use efficiency and yield stability under rain-fed agriculture. Agric. Water Manag. 2011, 98, 1364-1372. [CrossRef]

58. Centre for Independent Evaluations (CIE). Evaluation of ICRAF's Agroforestry Food Security Programme (AFSP) 2007-2011. In Final Report Submitted to IRISH AID; Center for Independent Evaluations: Lilongwe, Malawi, 2011.

59. Fanzo, J.; Boavida, J.; Bonis-Profumo, G.; McLaren, R.; Davis, C. Timor Leste strategic Review: Progress and Success in Achieving the Sustainable Development Goal 2. Centre of Studies for Peace and Development (CEPAD) Timor-Leste and John Hopskin University. 2017. Available online: https:/ /www.interpeace.org/wp-content/uploads/2017/06/TL-SR-May-15-V2-21_-May24-FINAL.pdf (accessed on 20 September 2021).

60. Food and Agriculture Organization (FAO). Evaluation of FAO's Contribution to the Democratic Republic of Timor Leste 20152018. Food and Agriculture Organizations of the United Nations, Rome, Italy. 2019. Available online: http://www.fao.org/3/ca5 653en/ca5653en.pdf (accessed on 12 February 2021).

61. Chandra, A.; Dargusch, P.; McNamara, K.E. How might adaptation to climate change by smallholder farming communities contribute to climate change mitigation outcomes? A case study from Timor-Leste, Southeast Asia. Sustain. Sci. 2016, 11, 477-492. [CrossRef] 
62. Ismail, C.J.; Takama, T.; Budiman, I.; Knight, M. Comparative study on agriculture and forestry climate change adaptation projects in Mongolia, the Philippines, and timor leste. In Climate Change-Resilient Agriculture and Agroforestry; Castro, P., Azul, A., Leal Filho, W., Azeiteiro, U., Eds.; Springer: Cham, Switzerland, 2019; pp. 413-430.

63. Intergovernmental Panel on Climate Change (IPCC). Summary for policy makers. In Climate Change 2014: Impacts, Adaptation, and Vulnerability; In IPCC Working Group II contribution to AR5; IPCC: Geneva, Switzerland, 2014. Available online: http: / /ipcc-wg2.gov/AR5/images/uploads/IPCC_WG2AR5_SPM_Approved.pdf (accessed on 3 March 2021). 